\title{
JUSTIFICATION OF THE PROSPECTS FOR INNOVATIVE DEVELOPMENT OF THE ENTERPRISE FOR THE EXTRACTION OF COPPER-CONTAINING BASALTS
}

\author{
Malanchuk Z.R. \\ National University of Water and Environmental Engineering \\ (NUWEE), Doctor of Technical Sciences, Professor, Department of \\ Development of Deposits and Mining, Ukraine
}

\begin{abstract}
Attracting investments for the development of natural resources enterprise needs deep justification of their efficiency. The conducted analysis of basalt processing technologies is indicative of fairly wide possibilities of its processing. Physical and mechanical properties and chemical composition of basalts offer an opportunity to use them in different industries.

The main problem is the presence of native copper in the deposits of the basalt quarry and the lack of technology for its extraction and processing. The development of this technology can provide a prospective and sustainable development of the enterprise in the future.
\end{abstract}

\section{Mining-and-geological and technological analysis of the} structures of deposits of copper-bearing basalts

Volyn basalts attract researchers with their unique properties as per mineralogical and chemical composition. Their isotopic age according to the potassium-argon method is 510-598 million years. They are represented by two modifications. Aphanitic basalts are black and dark-grey aphanites. Basically it is palagonite basalt. Its mineral composition is as follows: plagioclase - 36\%, pyroxene $33 \%$, glass $-19 \%$, palagonite $-6 \%$, ore mineral $-6 \%$. These basalts come out in the quarries of the villages of Berestovtsi, Yanova Dolyna, Ivanchi, Polytsi, etc. Amygdaloidal basalts are greenish-grey fine-grained rock with a large number of amygdules up to $15 \mathrm{~mm}$ in size. Mineral composition is the following: plagioclase, ore mineral (magnetite, titanic iron ore), apatite, rock glass. The main eruptions are in the Styr basin. Rock density is $\rho=2.65 \mathrm{~g} / \mathrm{cm}^{3}$. The chemical composition of the basic basalts is presented in the table 1 (weight content in percentage) [1-10].

In order to destroy the ore body and subsequently to extract the mineral product it is necessary to expend a significant amount of en- 
ergy. The development of new technologies for processing and preparing of the rock mass involves the use of the properties of rocks inherent in nature to reduce energy consumption for their destruction, increase liberation of ores and extraction of mineral products. Therefore, it is relevant to study the natural jointing of various rocks in a basalt mass, which can significantly change the approaches and principles of technological impact on them for further destruction and extraction of mineral products.

Geologists at the end of nineteenth and the beginning of the twentieth century took interest and began to study structures in rocks in the form of joints at the macro and mega levels, designated as autonomous blocks in the earth's crust by cracks and faults of different sizes. Generally split horizontal layers on the platform were detected beside vertical ones. Therewith the cracks had the regular arrangement - vertical and each of their systems had sustained stretching over a large territory, which is indicative of directed tectonical forces that are transmitted through the platform $[9,10]$.

Currently this factor is mainly not taken into account in the existing crushing plants. The grinding and preparation equipment and the processes accompanying them are aimed only at release of grains of the extracted mineral, not taking into account the structure and texture of the bearing rocks, so the task is to find the optimal size of the ore (or rock) constituent to obtain maximum ore release, maximum convergence of the size of the technological product and natural consistency of its structure.

The solution of the set task requires conduct of additional researches and will allow to form the physical process of mining recovery using new technologies and principles of ore processing and extraction of commercial components (obtaining quarrystone, break stone and chips of the correct geometric shape, reducing the number of splices in concentrate during enrichment, removing precious metal pick-ups without their destruction, etc.).

According to our empirical investigations the destruction of rock mass in joints occurs most vivid in centrifugal crushers and mills. For example, centrifugal crushers are used to produce breakstone of a cubic shape at relatively low energy consumption. The destruction of the ore body rock that contains metal pick-ups occurs without grinding of metal inclusions. 
Table 1

Chemical composition of basic basalts by quarries

\begin{tabular}{l|c|c|c|c|c|c|c}
\hline \multirow{2}{*}{ Coming out places } & \multicolumn{6}{|c}{$\mathrm{Chemical} \mathrm{elements} \mathrm{composition}$} & \multicolumn{2}{l}{} \\
\cline { 2 - 8 } & $\mathrm{SiO}_{2}$ & $\mathrm{TiO}_{2}$ & $\mathrm{Al}_{2} \mathrm{O}_{3}$ & $\begin{array}{l}\mathrm{Fe}_{2} \mathrm{O} \\
3\end{array}$ & $\mathrm{FeO}$ & $\mathrm{MnO}$ & $\mathrm{MgO}$ \\
\hline $\begin{array}{l}\text { village Khodosy, } \\
\text { village Hutvyn, } \\
\text { village Yanova Dolyna, } \\
\text { village Mydsk }\end{array}$ & 45,04 & 2,54 & 14,30 & 6,03 & 6,46 & 0,4 & 8,47 \\
\hline $\begin{array}{l}\text { village Berestovtsi, } \\
\text { village Yanova Dolyna } \\
\text { (quarry No.2) }\end{array}$ & 49,05 & 2,85 & 12,79 & 3,36 & 10,63 & 0,21 & 6,19 \\
\hline
\end{tabular}

Continuation of table. 1

Chemical composition of basic basalts by quarries

\begin{tabular}{|c|c|c|c|c|c|c|c|c|}
\hline \multirow[t]{3}{*}{ Coming out places } & \multicolumn{8}{|c|}{ Chemical elements composition } \\
\hline & $\mathrm{CaO}$ & $\mathrm{Na}_{2} \mathrm{O}$ & $\mathrm{K}_{2} \mathrm{O}$ & $\mathrm{P}_{2} \mathrm{O}_{5}$ & $\mathrm{SO}_{3}$ & $\mathrm{CuO}$ & $\mathrm{H}_{2} \mathrm{O}$ & Other \\
\hline & 8 & 9 & 10 & 11 & 12 & 13 & 14 & 15 \\
\hline $\begin{array}{l}\text { village Khodosy, } \\
\text { village Hutvyn, } \\
\text { village Yanova Dolyna, } \\
\text { village Mydsk }\end{array}$ & 6,58 & 2,42 & 0,48 & 0,17 & 0,3 & $0,03-1,2$ & 0,72 & 1,88 \\
\hline $\begin{array}{l}\text { village Berestovtsi, } \\
\text { village Yanova Dolyna } \\
\text { (quarry No.2) }\end{array}$ & 9,38 & 2,78 & 2,05 & 0,57 & 0,2 & 0,22 & 0,8 & 2,41 \\
\hline
\end{tabular}

Apparently the destruction in this case occurs along the so-called reticular planes, which is characterized by the number of nodes (atoms, ions) of the plane lattice per unit of its area (according to the Bravais theory). Apparently this rule applies not only to crystals, but also to rocks in general. The obtained results need additional applied and theoretical researches. The brief review of the theoretical aspects and analysis of existing ideas about the jointing of rocks that is carried out with the participation of the author indicates on the topicality and prospects of such researches. Recent works show the efficiency of accounting of the structure of deposits when grounding the parameters of their extraction and processing. The main laws of development of natural jointing of igneous rock deposits on the territory of Zhytomyr region are determined in the work, a relationship between the orientation of tectonic faults and cracks of natural joints, as well as between the location of faults and deposits of trim stone is revealed. It is established that the law of development of natural frac- 
tures of joints is tributary to the normal law. Account of the peculiarities of the mass structure and the anisotropism of the trim stone made it possible to improve the sawing of blocks and to reduce its losses.

In the work [11-13] on the basis of established connection between the mechanism of creation of the oriented structure of bearing rocks and their peculiarities is recommended the character of the mechanical impact at break. It was established for the first time that at static load the fracture pattern of the intrusive rock is determined by the peculiarities of the microstructure - the orientation and degree of orientation of microcracks, and under dynamic load the nature of destruction is influenced by the macrostructure of the mass - orientation of microcracks and the degree of their opening. Based on the results of the investigations the technology of severance of granite monoliths from the mass was improved and the percentage of blocks output was increased.

Based on the positions of blocky structure and cleavage the studies of basalt coming out under the conditions of the Rafalivskyi and Berestovetskyi quarries showed their high cleavage (working height is $15-20 \mathrm{~m}$ ), clear cleavages, limited by vertical and horizontal cracks. Currently the extraction of basalt is done for break stone. The technological scheme of extraction includes open cut mining (the thickness of the sand-chalk layer of opening is 2-5 m), drilling of wells in accordance with the blasting pattern, undercut of stope that is followed by excavator loading in road transport for delivery to the crushingand-sorting site. Salable material in the form of break stone in three classes of fineness $(10 ; 10-20 ; 20-40 \mathrm{~mm})$ is obtained using pin breakers, gyratory cone breakers, centrifugal crushers and vibratory screens.

In the process of analysis of mined and crushed rock, especially in basalts and lava-breccias it is possible visual selection of barrelcopper in the form of different size chips. Pick-ups in general have branched structure and weigh from several to hundreds of grams. On a massive scale are found chips of copper with the weight of 10-40 grams. The biggest pick-up was found in Rafalivskyi quarry and it weighs $1.4 \mathrm{~kg}[14,15]$. 


\section{State of exploitation maturity of the process of extraction and processing of copper-bearing basalts}

Over the last years are carried intensive researches and commercial exploitation of basalt deposits in Rivne-Volyn district due to detected valuable raw material types. Trappean structure of basalt deposits, diversity of mineralization forms and mineral rock composition even at the state of art of exploration maturity are indicative of the necessity of complex approach in the deposits development, moreover it refers to the mining and processing technology and to the usage of final product. For example, multilayer structure of basalt mass that contains directly basalts, tuffs of different mineral composition, lava-breccias with intensive inclusions of barrel-copper and ore layers with inclusions of precious metals in bulks, call in doubt the rationale of basalt extraction only for production of break stone and face slabs.

Multifactority of the composition, different cover thickness and character of bearing rocks need complex technology of extraction (open-cut or shaft mining, hydraulic mining by boreholes). In such a way the diversity of mineral deposits requires complex of the applied influence means on the deposits and familiarization of different processes of mining industry. Suffice it to say that the territorial location of deposits in protected areas leads to reduction in the open-cut mining development method from an environmental point of view. The best in this case is the wellfield method based on the transfer of a mineral deposit into a mobile state in situ. In this case compared with traditional (open-cut and deep-mining methods) wellfield methods of extraction of mineral deposits have two fundamental differences:

- release, preparation and development of the deposit is done through well drilling and as a rule the extraction is done from the earth surface;

- mineral deposit is extracted to the surface preatreated by one of the processing methods, for example, by hydraulic washing-out. In this case the features of the ore body are used during elaboration of technology of its processing in the place of bedding.

At the same time the work is planned to manage the rock mass over the worked out space and are taken into account the processes that take place in the mass. According to the complex of works under consideration in Rivne-Volyn region a scientific base has been devel- 
oped for hydraulic mining by boreholes technology for the extraction of heavy metals from placer accumulations and legacy placers. In the stated works the implementation of the concept of exploration, commercial preparation and development of mining of valuable minerals in Rivne region is described, the directions for increasing the degree of their concentration at the places of accumulation with leaving soft bearing rocks in underground conditions are developed.

During the former investigations of Rivne mining party it was established not only diversity and volume of commercially valuable mineral deposits but also the stated conditions of their bedding, thickness of beds and percentage content of each mineral deposit, pattern of their occurrence in the thickness of basalt deposit [14, 15]. Therefore the feasibility of a comprehensive not only production, but also processing is determined by the capabilities of the deposit and modern technologies, the requirements of the ecological situation in the region and the relevance for the national economy of deposit derivative products.

For the accuracy of the concept of complex conduct of mining and processing works in Volyn region it is necessary in the first instance to conduct short analysis of the deposit capabilities.

Researchers have a profound interest to the natural minerals zeolites, since there is an experience of their practical use in the world. Japanese scientists, and subsequently industrialists of the USA, China, Russia, Bulgaria and Ukraine, where the zeolite deposits were discovered, have established a positive effect on crop yields when applied to the soil, as well as feed additives for animals and poultry. Great prospects have been established for the use of zeolite-smectite tuffs to combat technogenic pollution of the environment with radionuclides and heavy metals. Taking to account the scale of the contaminated territories, especially in the industrially developed regions of Ukraine, large areas require preventive treatment, so the extraction of zeolites is relevant. Tuff reserves in the basalt quarries of Rivne region are estimated at about 20 million tons. They underlay at a depth of 10 meters or more, so they can be mined by the open-cut mining and considering the solubility of some types of tuff downhole technology is also possible.

According to the studies of the mineral composition of zeolitesmectite cinerites of Rivne region the main minerals in their composi- 
tion are zeolites, smectites, iron-bearing dispersed minerals and aluminosilicates. Most of them have a crystalline lattice of the platesheet type, which determines the high specific surface of individual particles that have an exposed cavity. Therefore minerals actively interact with water and are successfully used for its purification [16, $17,18]$.

When interacting with water smectite tuff minerals that have an expensive crystalline lattice increase or decrease in volume by up to 20 times, when dehydrated the volume of the mineral decreases sharply, the plastic property of wet minerals increases, therefore, a hydraulic mining by boreholes technology can be used.

The important component of trappean structure of basalts in Volyn is lava clastic breccia that underlay in the bottom of basalt layers. The geologists of Rivne regional geological office among the lava clastic breccia of Rafalivka ore cluster opened perspective deposits of barrelcopper with different percentage content. It has to be mentioned that alongside with the main basalt mass in the content of rock the significant role play aqueous and pyroclastic rocks that occupy around 50\% of its stratigraphic framework. Altogether they compile (from the bottom up) four rock formations: Horbashi (gritstone sandy with admixture of pyroclastics); Zabolotsi basalt with tuff interburdens; Babyn tuff and Ratne basalt with layers of lava clastic breccia, tuff bedding rocks, tuffites and tuff glomerations. Copper bearing lava-breccia are cropping out in the range of quarries of basalt extraction. Lavabreccia underlay in the tuffs of Babyn rock formations, at the core of the first (from the bottom) basalt flow of Ratne rock formations in the form of bedding rock with the efficiency of 1.0-0.7 m. The content of copper in lava-breccias changes from 0.04 to $5.0 \%$. The copper is in the form of pick-ups of different coarseness and form. The detected pick-ups have weight of more than 700 grams. Shallow bedding of productive strata in the quarries and borehole method cause high prospects for the detection of deep fields of barrel-copper and precious metals. Beside copper in the content of ore bodies were detected silver, gold, palladium, rhodium, platinum that show economic interest and however currently not being under development need careful examination for preindustrial preparation for complex field development.

The study of the peculiarities of deposits of barrel-copper in 
Zhyrychi and Rafalivka allowed establishing that copper mineralization has several morphotypes with different localization conditions. The classification of barrel-copper of Volyn is given in the work and the main places of its location in ore bodies are defined. So diffuseporphyry and laminated-porphyry barrel-copper is localized mainly in flow-laminated, slightly changed phaneric basalts in the low part of powerful flows. Its concentration hardly ever exceeds $0.3 \%$ in basalts and in the basaltic tuffs of Babyn rock formation were found copper concentrations up to $1.0 \%$ in the ore interval of $1.5-2.0 \mathrm{~m}$.

Vein-disseminated barrel-copper is spread in the cracks and veins of hydrothermal mineralization of basalts and tuffs. Its concentration is very uneven and increases in the places where stringer-porphyry mineralization is put upon the bedrocks with dispersed disseminated copper. A high copper content was found in the relatively thin bedrocks of the lava clastic breccias at the base of the lower basalt flow of the Ratne rock formation. The copper content in them varies from 0.04 to $5.0 \%$. Further studies showed that finer inclusions of barrel copper make up the bulk in the ore bodies of amygdaloidal basalts, tuffs and tuff breccias, in the quartz reefs of the Zhyrychi and Rafalivka volcanic rocks $[2-4,10,17]$.

Studies with the participation of the author of this work as a result of spectral analysis of rocks of the Rafalivka basalt quarry established that in the aphanitic basalt with stringer-porphyry barrel-copper mineralization the copper concentration is in the range of $0.43 \%$. In lavabreccia of the basalt content the percentage of copper is in the range of $4.0-0.174 \%$, and in basalt tuffs with dispersed disseminated and veined porphyry mineralization the percentage of copper is about $0.7 \%$. In this case there is an uneven content of copper in all three rocks. Taking to account the variety of morphotypes of barrel-copper mineralization there is a need for their separate study to search for processing and extraction methods. Previous studies of the authors have shown that each type of mineralization requires an individual approach. In the case of coarsely disseminated copper (more than 3-5 $\mathrm{mm}$ ) it is advisable to use the method of crushing and, especially, grinding without violating the integrity of the pick-ups. In this case an incomplete cycle of their enrichment is possible, which eliminates such technologically complex operations as precipitation and flotation, since it is possible to replace them with fine classification and 
electric separation.

Finely disseminated mineralization needs fine crushing of bearing rocks with the following methods of flotation concentration or combination of fine crushing, grinding with the following fine classification (less than 50 microns) for separation of finely ground bearing rock from small copper pick-ups. Therewith the important requirement is the exclusion of regrinding of disseminated copper.

Taking to account the abovementioned peculiarities of the technology in the Institute of Geotechnical Mechanics of the National Academy of Sciences of Ukraine was developed internally rolling conical mill that allows limiting the fragmentation size of finely disseminated copper. It conducts its preliminary preparation and the task of this process is assurance of output coarseness for grinding on the specially developed centrifugal mill where the metal inclusions of barrel-copper are not ground but only deformed, while bearing rocks are ground until micron level releasing finely disseminated copper inclusions. Loading out of the centrifugal mill is done on the vibrating sieve of fine classification with the aim of separation of the pickups (oversieve product) from dead ground (undersieve product). A further process operation is to separate the pick-ups from the splices by electric separation or metallurgical extraction. Crushed basalt after screening at a screen is a valuable chemical raw material (basalt casting, thermal insulation wool, etc.) $[14,15]$.

It should be noted that the abovementioned basic operations of the technology for the extraction of barrel-copper have been tested on lava breccias, however, for brown tuffs with high mineralization with titano-magnetites and finely disseminated barrel-copper they can be used for dry enrichment of these metals from tuff. After fine classification tuff screening products are also valuable chemical raw material for the production of fertilizers, feed additives and water purification filters.

The significant experience has been gained in the quarry mining of ores, which makes it possible to borrow the most effective technical solutions by the technology for extraction and usage of necessary equipment. The ore preparation processes for ores of different mineralization and percentage composition require an individual solution, and the issue of the extraction of barrel-copper in the basalt deposit on an industrial scale in Ukraine is being solved for the first time, 
and, nevertheless, the available experience allows us to solve the problem brought up in the work [19-26].

Thus the complex processing and usage of basalt raw material is technically feasible. The process requires pre-industry verification, proving, study of features, selection of equipment and development of recommendations for its industrial development.

3. Barrel-copper extraction as the direction of innovative development of the Private Joint-Stock Company "Rafalivka basalt quarry"

One of the main factors in the development of the mining industry enterprise in the long term is the implementation of innovations. Precisely thanks to innovations that such important tasks are solved: in the interests of business entities - the competitiveness of the enterprise, its flexibility to changes of external environment increases, financial stability enhances; for consumers - the number of purchase alternatives is increasing and the circle of satisfied needs is expanding.

The topicality and importance of solving of these tasks is due to the great variability of the business environment and, accordingly, excessive risks hinder the process of innovation implementation in the enterprise.

The main directions of innovations implementation at an industrial enterprise in the strategic context of its activities are product diversification, its improvement and market diversification, as well as the introduction of a differentiation strategy.

The implementation of innovations based on product diversification involves the release of new products or products that are manufactured on the basis of the application of new technologies not previously used by the enterprise, and market diversification involves the entry by the enterprise on the new markets or new segments of the market where it acted up till now.

Attracting investments for the development of an enterprise of mining industry requires a deep justification for their efficiency. The problem of investment efficiency has always occupied an important place among the urgent problems of economic science. Interest in it arises at different levels of economic management - from owners of business entities to state leaders. Efficiency belongs to the most general economic categories peculiar to any branch of industry. 
First of all it is necessary to clearly define what "efficiency" is, since this concept as the main goal of the functioning of any activity is rarely subject to theoretical consideration precisely because of the ambiguity of perception. Also often in modern literature such concepts as "efficiency" and "performance" cause a lot of inconsistencies. In order to be successful over extended periods, to survive and achieve own goals, the organization has to be both efficient and effective.

Thus, by its main attribute, efficiency is the result of activity obtained per unit of used (spent) resources. Herewith the obtained result can have a different expression, since different resources can be used to achieve the effect. However whatever the result and resources are taken, the efficiency always reflects their correlation, since its essence ultimately manifests itself through the dynamics of this ratio and the consistency of the latter.

Economic justification of investments in the given research is conducted in conventional units with the aim to show its efficiency and to reflect traditional for Ukraine correlations of different types of expenses by the example of one of mining enterprises of Ukraine that is located in Rivne region - Private Joint-Stock Company "Rafalivka basalt quarry".

According to conducted analysis of external environment we can arrive at decision that the enterprise is insufficiently using the existing manufacturing resources. Beside the market where it sells own products is narrowing. That is why the enterprise has to strengthen own positions and to decrease the dependence on changes in sales of the main types of products. In such case it is reasonably to apply innovative approaches in the enterprise in order to ensure survival and development in long-term perspective.

In order to improve market position of the enterprise it is necessary to analyse innovative capabilities of the enterprise. According to the results of SWOT analysis in the Private Joint-Stock Company "Rafalivka basalt quarry" were detected unused capabilities of the enterprise, namely the presence of copper in the quarry deposits and absence of technology of its extraction, also to the strong points of the enterprise it is possible to refer physical and mechanical peculiarities and chemical composition of basalts, which gives the possibility to expand the range of products. 
Basalt quarry

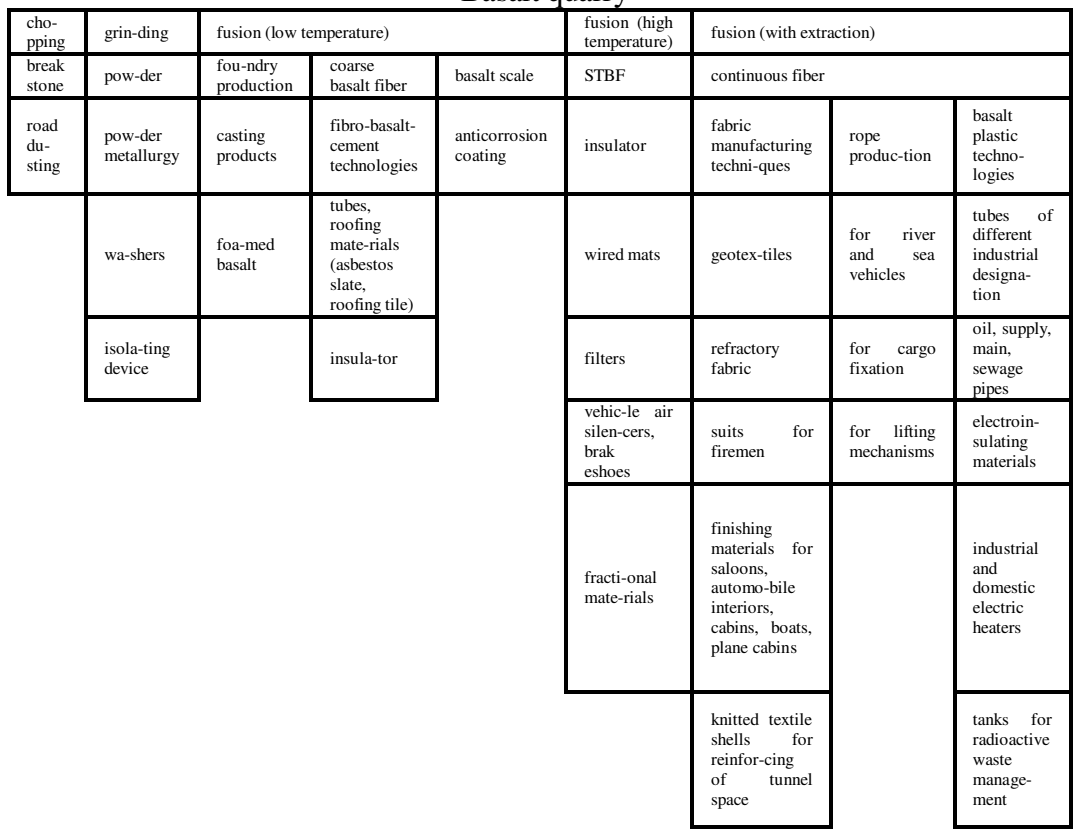

Fig. 1. Scheme of technological capabilities of basalt usage

The analysis of basalt processing technologies demonstrates that there are wide enough opportunities for its processing. Physical and mechanical characteristics and chemical composition of basalts enable their application in various economy branches (fig.1).

Usually the basalt is crushed to crushed stone and is mainly used for road paving. That is, the processes of crushing or shredding are carried out.

But outside of Ukraine wide development receive technologies on basalt melt on manufacturing of thermal insulating materials, pipes, a basalt thread, a tile and other.

Conditionally, basalt casting can be divided into three types:

1. Fusion (low temperatures):

1.1. Foundry production (casting products, foam basalt);

1.2. Coarse basalt fiber (fiber basalt-cement technologypipes, roofing materials (cipher, roof tile), insulation);

1.3. Basalt scale (anticorrosive coating). 


\section{Fusion (high temperatures):}

2.1.Super-thin basalt fiber (STBF) ( a sheet of super-thin basalt fiber), insulant, filters, vehicle sound dampers;

2.2. Fiber basalt plastic technologies - pipes for various purposes, fractional materials, brake pads for vehicles and railway transport, for lifting mechanisms of various industries.

3. Fusion with extraction (continuous fiber):

3.1. Textile manufacturing technology (geotextile materials, refractory fabrics: firefighter suits, covering materials for car showrooms, ship cabins, aircraft showrooms, living quarters, offices, knitted textile shells for strengthening the tunnel goaf);

3.2. Manufacture of ropes (for sea and river transport, lifting mechanisms of various purposes, for fastening of cargoes during transportation);

3.3. Basalt-plastic technologies (pipes of different purpose: oil-gathering, drainage, pipeline, sewerage, water supply; electrical insulating materials: stamping plates, domestic and industrial electric heaters, cylinders and containers for various purposes, containers for disposal of radioactive waste, basalt cement reinforced constructions).

A lot of basalt is exported to Poland, where it is used for basalt casting instead of on highway "pillows" laying. The calculation is simple: finished basalt products cost at least several hundred times more expensive than raw materials. The most economical is the production of high-tech products. Thus, the production cost of one kilogram of basalt crumb, taking into account all the expenses is equal to USD 0.01, while the same amount of basalt thread costs USD 1.3, and one square meter of thermal protective fabric - USD 6-8.

Thus, physicomechanical and chemical properties of basalts of PJSC "Rafalivka basalt quarry" allows its usage for organization of new productions and production types that will enable the company to take a competitive position in the market.

We have analyzed the opportunities for native copper producing. The first findings of native copper were found in Volyn basalts in the 30 s of the last century. Since then, their unique origin has been intensively studied, exploration work on copper ores has been carried out and areas of rich copper mineralization have been identified. One of the most promising is the Rafalivka ore cluster in the Rivne region, established by the Rivne geological expedition. 
Technologists at Rafalivka basalt quarry carried out research work and concluded that the basalt deposits have a trappean structure, the main components of which are layers of basalt, lava breccias and tuff. And the highest native copper content is observed namely in lava breccia (Fig. 2). In basalts and tuffs, copper is present in the form of veins and inclusions. When chopping, it can be separated from the enclosing rocks.

During the research, copper pick-ups from 0.1 to $1.4 \mathrm{~kg}$ were found. In basalt and tuff, copper contains in the form of veins and inclusions.

Copper holds one of the leading positions both in production volume among metals and in industrial consumption volume among industries of developed countries. At the current stage of the world economy development, there is a tendency for increasing the rates of copper consumption, which is also peculiar for Ukraine (metallurgical complex, mechanical engineering, electrical engineering, communications, electronic industry, etc.). The annual demand of the Ukrainian economy for copper is huge and, according to the Program of Nonferrous Metallurgy Development of Ukraine, is up to 200 thousand tons, the cost of which according to various estimates can be UAH 30 billion per year. Consumption of copper in Ukraine is based on imported and domestic secondary raw materials.

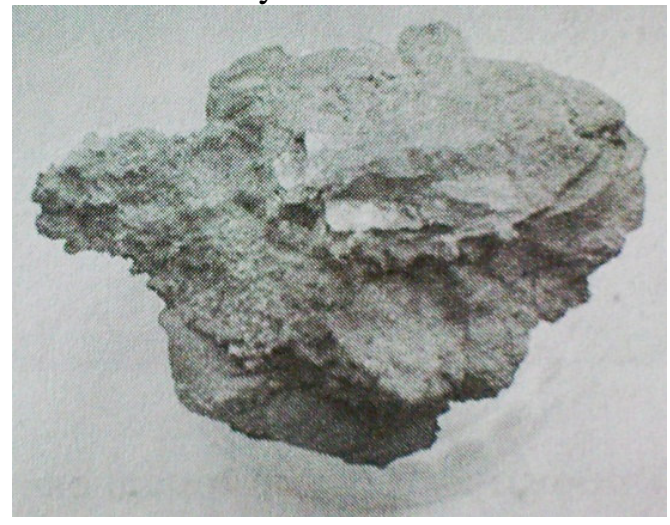

Fig. 2. Modified basalt fragment with a leaf-shaped copper pick-up (on the left) from the Rafalivka basalt quarry

Now Ukraine has no explored copper deposits, but the prospect of 
creating its own mineral resource base of this metal is quite significant, which is associated with deposits of native copper at PJSC "Rafalivka basalt quarry".

Therefore, for PJSC "Rafalivka basalt quarry" this area of development is promising for ensuring competitive advantages in the long term. After all, copper in Ukraine is a unique product.

Copper is extremely important for electro technical and other industrial sectors. At present time, the deficit of copper in Ukraine is sorely felt, that is why the works on searching for this important nonferrous metal have been activated. The considerable needs of copper in Ukraine are met by its imports (currently about 250 thousand tons per year). Copper is not mined in Ukraine - only geological exploration works are carried out. Within the country, there are enterprises that are withdrawing copper from secondary resources. This refers to electrical, radio and electronic equipment or parts thereof that have reached the end of their working life. The cost of copper in this case is high due to the labor intensity of its extraction. In addition, the chemical purity of this copper is low, and in this case the matter is more about alloys. Copper is widely used in the manufacture of products for various purposes: pipelines, chemical equipment, electrical devices, etc. Copper is resistant to oxidation, bacteria and viruses and it detritions slowly. Copper pipes began to be used more actively due to their mechanical properties, low density of pipe walls and simplicity of installation. The copper pipes connection is simple and reliable. It is believed that copper is perfectly resists corrosion. In terms of its electromechanical properties it is the same as noble metals. Copper pipes also prevent the bacterial growth in water. This is extremely important, especially for systems that supply hot drinking water. Application of copper is advisable in systems supplying both cold and hot drinking water, heating systems, solar energy storage systems, gas and liquid fuel supply systems, refrigeration industry. This means the multiversity of copper use, which is associated with its special physical properties.

There is no environmental threat from native copper mining. In fact, quite a simple technological scheme of its processing is used: shredding, washing and gravity treatment, during which heavier metal particles settle, as shown in figure 3 .

The tuff of quarry mining, being in the refuses, has a particle size 
up to $200 \div 300 \mathrm{~mm}$, and after the softening - $50 \div 100 \mathrm{~mm}$. For further processing it needs to be crushed and shredded. On the basis of the analysis of tuff particle size composition after crushing and shredding, results of softening, there was developed a scheme of ore preparing of tuff for complex processing taking into account its strength, mineral composition and necessary particle size composition. Scheme shown in the figure 3 , consists of a chain of successive devices: receiver cone 1 , vibrating feeder 2 , jaw crusher 3 , belt loader 4 , roll crusher 5 , vibrating screen 6 , belt loader 7 , roller mill 8 , fineshredding vibrating screen 9 , belt conveyor 10 magnetic separator 11 and electric separator 12 .

The selection of equipment parameters is made on the basis of the obtained research results. For example, based on the maximum magnetic susceptibility of tuff (1.3 tesla), the magnetic separator should provide this strength of the field. Roller mill and vibrating screen should ensure a particle size of $0.3 \div 0.1 \mathrm{~mm}$ for effective magnetic and electrical separation. The design values of the roller crusher (diameter of the rollers, clearance between them, speed) are determined depending on the established original tuff size. The parameters of the jaw crusher are also selected based on the same considerations. The efficiency of the scheme has been tested in laboratory conditions. In the course of research it was determined that as a roller mill 8 , it is advisable to use an intra-roller cone vibratory mill designed by the IGTM NAS of Ukraine, since it will prevent significant fragmentation of tuff (less than $0.1 \mathrm{~mm}$ ) by selecting the winding pitch and height of the cone. As it has been established earlier, such fragmentation sharply reduces the efficiency of magnetic and electrical separation [30].

For operations of small and fine classification of shredded tuff to the necessary for effective magnetic and electrical separation in the laboratory conditions of modeling the technological line were used vibrating screens with dynamically active screening surface and additional metal net with the necessary size of cells. The screen of the IGTM NAS of Ukraine design showed efficiency up to $85-90 \%$ in the class of particle size of 100 microns, and it is recommended for equipping the presented technological scheme.

Associated products of copper extraction are basalt (basalt chips, sifting) and tuff. 
For a long time tuffs were not in practical demand and during the exploitation of basalt deposits they were moved to dumps. At this time, it was found that due to the significant content of sorbents (50$60 \%$ ) tuffs demonstrate important sorption, selective and cationic exchange capacities and can be used as:

- impurities in the feed concentrates for the purpose of sorption of artificial radionuclides, removal of toxins from animals' bodies, supplementary feeding of feed ration with microelements deficient for the Polissia zone (copper, vanadium, chrome, manganese, etc.);

- as natural inorganic sorbent - ameliorant during decontamination of soils in the zone of radioactive contamination;

- as a natural dye - filler in the manufacture of oil and silicate brown paints.

For practical use, tuff raw materials do not require pre-equipment. The near-surface conditions of occurrence allow surface tuff mining, first of all, from the bottom of the pit without expenses for overburden removing.

The availability of access roads and mining infrastructure at the existing quarry also makes tuff exploitation cheaper.

Thus, the Rafalivka basalt quarry has quite unique resource deposits of native copper, both in economic and environmental aspects.

If to pay attention to the fact that copper is not mined in Ukraine at all (the country's demand is met by exports), then such activity will provide the company with the future development prospects.

Mastering of the copper mining technology, which lies in the deposits of the quarry, is extremely important to ensure the financial stability of the enterprise, and obtaining competitive advantages and development in the longer term.

The main problem is the presence of native copper in the basalt deposits of the quarry and the lack of technology for its mining and processing.

The mastering of this technology will be able to provide perspective stable development of the enterprise in the future. 


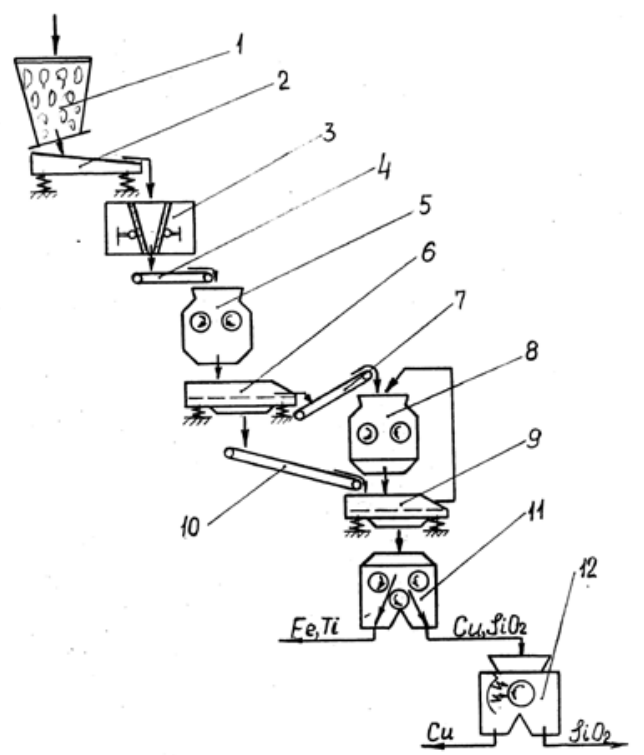

Fig. 3. Tuff ore preparation scheme

Consider several alternatives of mastering native copper mining technology.

$>$ Proprietary solution of native copper mining technology

For mastering technology for the mining of native copper and related minerals, the enterprise can begin to develop such technology on its own by conducting research and development and trial manufacturing. After all, during the research work experts and geologists justified a quite simple technological scheme of its processing: shredding, washing and gravity treatment, during which heavier metal particles settle.

Advantage: application of this alternative will provide the company with its own technology.

Disadvantages: low professional-qualification level of specialists of the enterprise in this direction, high expenses for staff training and research and development, high risk of failure to obtain the desirable results. 


\section{$>$ Purchase of a patent for the native copper mining}

In Ukraine there are no patented technologies for copper mining, there are only geological exploration works, according to which it was established that deposits of native copper were found in Volyn and Polissia.

There are only two known deposits of such copper in the world near the Great Lakes in the USA and in China, respectively, there exists such technology, developed and patented. Therefore, it is possible to purchase a copper mining patent from these manufacturers.

Advantages: Purchase of the patent will save the time required to carry out research and development and will enable to start copper mining immediately, to train employees of the quarry with involvement of highly professional specialists from abroad.

Disadvantages: such an alternative would require large investment of funds - attraction of significant credit resources. Today in the conditions of economic instability, it is quite risky for the enterprise to take big credits, since the enterprise does not have own funds necessary for realization of such variant of actions. Purchase of such a patent and personnel training will cost the company a lot.

But there is a great risk associated with the fact that the technologies in the USA and China were developed in accordance with their quality characteristics of basalt lava. For example, the copper content in ore concentrate in the USA is $99.5 \%$ and in the Rafalivka basalt quarry is only between 0.2 and $5 \%$. Therefore, the applied technology may not be suitable for the mining conditions at PJSC "Rafalivka basalt quarry".

At the time of technology development for the native copper mining were issued Ukrainian patents and certificates of authorship (declaration patent of invention No. 59882A. Ukraine. Gravitational magnetic separator MKI 7B 03C 1/04, declaration patent of invention No. 50098A. Ukraine. Screen. MKI 7B 07B 1/40, declaration patent of invention No. 70428A. Ukraine. Vibrating screen. MKI 7B 07B 1/46). In recent years, scientists of IGTM NAS of Ukraine and NUWEE together with employees of PJSC "Rafalivka basalt quarry" were searching for investors to engage in the manufacturing process.

The investment required for the realization of this project is 10 million common units. In this case, the undistributed profit of PJSC "Rafalivka basalt quarry" may amount to 1.767 million c.u., of which 
1.5 million c.u. may be attracted to the project.

Thus $17 \%$ of received profit from realization of investment can be credited to the account of PJSC "Rafalivka basalt quarry", thus the administration of quarry will undertake organizational and legal issues on realization of production. Preliminary expenses for implementation of the future investment proposal are given in Table 2.

Table 2

Cost estimates

\begin{tabular}{c|l|c|c|c|c|c|c}
\hline $\begin{array}{l}\text { Ser. } \\
\text { No }\end{array}$ & $\begin{array}{l}\text { Name of the expense } \\
\text { component }\end{array}$ & 1 & 2 & 3 & 4 & 5 & Total \\
\hline 1 & Expenses, in total & 9813,75 & 3615,94 & 2419,60 & 2391,82 & 2378,50 & 20620 \\
\hline 2 & $\begin{array}{l}\text { incl. equipment purchase } \\
\text { int }\end{array}$ & 5250 & & & & & 5250 \\
\hline 3 & $\begin{array}{l}\text { equipment installation } \\
\text { and manufacturing pro- } \\
\text { cess setup }\end{array}$ & 900 & 200 & & & & \\
\hline 4 & $\begin{array}{l}\text { research and develop- } \\
\text { ment, preparation of pilot } \\
\text { production }\end{array}$ & 1500 & 950 & & & & 1100 \\
\hline 5 & Operating expenses & 1908,75 & 2085,94 & 2039,60 & 2011,82 & 1998,50 & 10045 \\
\hline 6 & Non-production expenses & 255,00 & 380,00 & 380,00 & 380,00 & 380,00 & 1775 \\
\hline
\end{tabular}

The equipment needs for the establishment of the production process are given in Table 3.

Table 3

Equipment needs

\begin{tabular}{c|l|l|c|c|c}
\hline $\begin{array}{c}\text { Ser. } \\
\text { No }\end{array}$ & \multicolumn{1}{|c|}{$\begin{array}{c}\text { Measurement } \\
\text { unit }\end{array}$} & $\begin{array}{c}\text { Number } \\
\text { per pro- } \\
\text { ject }\end{array}$ & $\begin{array}{c}\text { Price per } \\
\text { unit, thou- } \\
\text { sand c.u. }\end{array}$ & $\begin{array}{c}\text { Value, } \\
\text { thousand } \\
\text { c.u. }\end{array}$ \\
\hline 1 & \multicolumn{1}{|c|}{2} & 3 & 4 & 5 & 6 \\
\hline 1 & Jaw crusher & pcs & 2 & 150 & 300 \\
\hline 2 & Centrifugal crusher & pcs & 2 & 150 & 300 \\
\hline 3 & Vibrating screen & pcs & 8 & 70 & 560 \\
\hline 4 & Conveyer & pcs & 5 & 30 & 150 \\
\hline 5 & Mechanical loader & pcs & 2 & 150 & 300 \\
\hline 6 & Electrostatic separator & pcs & 4 & 100 & 400 \\
\hline 7 & Wash box & pcs & 5 & 25 & 125 \\
\hline 8 & Mill & pcs & 4 & 100 & 400 \\
\hline
\end{tabular}


Continuation of table. 3

\begin{tabular}{c|l|l|c|c|c}
\hline 1 & \multicolumn{1}{|c|}{2} & 3 & 4 & 5 & 6 \\
\hline 9 & Truck & $\mathrm{pcs}$ & 2 & 300 & 600 \\
\hline 10 & $\begin{array}{l}\text { Equipment kit for equipment } \\
\text { analysis }\end{array}$ & $\mathrm{pcs}$ & 2 & 200 & 400 \\
\hline 11 & $\begin{array}{l}\text { Overpasses for equipment } \\
\text { and foundation }\end{array}$ & $\mathrm{pcs}$ & 18 & 65 & 1170 \\
\hline 12 & Bin & $\mathrm{pcs}$ & 14 & 10 & 140 \\
\hline 13 & Blasting lead & $\mathrm{pcs}$ & 15 & 17 & 255 \\
\hline & Total & & & & 5250 \\
\hline
\end{tabular}

The total capital investment is 10000 thousands c.u. The total capital investment is 10000 thousands c.u. Of which the equipment purchase amounts to 5250 thousand c.u., its installation and adjustment of the production process amounts to 900 thousands c.u. and 200 thousand c.u. respectively in the first and second year of the project implementation. Expenses for the implementation of research and development works and preparation of trial production in the first year will amount to 1500 thousand c.u. (investments of the quarry), and in the second year - 950 thousand c.u.

Operating and non-production expenses of innovative products manufacturing are given in Table 4.

Table 4

Operating and non-production expenses of innovative products manufacturing

\begin{tabular}{c|l|c|c|c|c|c|c}
\hline Ser. No. & Name of the expense component & 1 & 2 & 3 & 4 & 5 & Total \\
\hline $\mathbf{1}$ & Expenses, in total & $\mathbf{2 1 6 3 , 7 5}$ & $\mathbf{2 4 6 5 , 9 4}$ & $\mathbf{2 4 1 9 , 6 0}$ & $\mathbf{2 3 9 1 , 8 2}$ & $\mathbf{2 3 7 8 , 5 0}$ & $\mathbf{1 1 8 1 9 , 6}$ \\
\hline $\mathbf{2}$ & Oncluding & & & & & & \\
\hline 2.1 & Wages & & & & & & \\
\hline 2.2 & Social contributions & 540,00 & 720,00 & 720,00 & 720,00 & 720,00 & 3420 \\
\hline 2.3 & Water and Wastewater Treatment Plant & 10,00 & 10,00 & 10,00 & 10,00 & 10,00 & 50 \\
\hline 2.4 & Electricity, heating & 202,50 & 270,00 & 270,00 & 270,00 & 270,00 & 1282,5 \\
\hline 2.5 & Drilling and blasting services & 200,00 & 250,00 & 300,00 & 350,00 & 400,00 & 1500 \\
\hline 2.6 & & & & & & & \\
\hline 2.7 & Preliminary overburden removing & 100,00 & 100,00 & 100,00 & 100,00 & 100,00 & 500 \\
\hline
\end{tabular}


Continuation of table. 4

\begin{tabular}{c|l|c|c|c|c|c|c}
\hline $\mathbf{2 . 8}$ & Total Operating expenses & $\mathbf{1 9 0 8 , 7 5}$ & $\mathbf{2 0 8 5 , 9 4}$ & $\mathbf{2 0 3 9 , 6 0}$ & $\mathbf{2 0 1 1 , 8 2}$ & $\mathbf{1 9 9 8 , 5 0}$ & $\mathbf{1 0 0 4 4 , 6}$ \\
\hline $\mathbf{3}$ & Non-production expenses & & & & & & \\
\hline 3.1 & Administrative expenses & 145,00 & 145,00 & 145,00 & 145,00 & 145,00 & 725 \\
\hline 3.2 & Advertising expenses, marketing & & 125,00 & 125,00 & 125,00 & 125,00 & 500 \\
\hline 3.3 & Staff training & 95,00 & 95,00 & 95,00 & 95,00 & 95,00 & 475 \\
\hline 3.4 & Environmental Protection & 15,00 & 15,00 & 15,00 & 15,00 & 15,00 & 75 \\
\hline & Total non-production expenses & $\mathbf{2 5 5 , 0 0}$ & $\mathbf{3 8 0 , 0 0}$ & $\mathbf{3 8 0 , 0 0}$ & $\mathbf{3 8 0 , 0 0}$ & $\mathbf{3 8 0 , 0 0}$ & $\mathbf{1 7 7 5}$ \\
\hline
\end{tabular}

Estimated production and sales volumes of innovative products in natural indicators are given in Table 5.

Table 5

Expected production and sales volumes of innovative products in natural indicators

\begin{tabular}{l|l|l|c|c|c|c|c|c}
\hline No & $\begin{array}{c}\text { Innovative prod- } \\
\text { uct name }\end{array}$ & $\begin{array}{c}\text { Measurement } \\
\text { unit }\end{array}$ & 1 year & 2 year & 3 year & 4 year & 5 year & $1-5$ years \\
\hline 1 & Basalt & ton & 4000 & 6000 & 8500 & 8500 & 8500 & 22000 \\
\hline 2 & Native copper & ton & 150 & 200 & 250 & 300 & 350 & 1100 \\
\hline 3 & Tuff & ton & 900 & 1500 & 2000 & 2000 & 2000 & 8000 \\
\hline
\end{tabular}

We accept that the following price is formed in the market: basalt - 60 c.u./t, copper - 60000 c.u./t, tuff - 40 c.u./t. The expected volume in cash equivalents is calculated in Table 6.

Table 6

The expected sales volume of innovative products

\begin{tabular}{l|l|l|l}
\hline Years & $\begin{array}{l}\text { Number of } \\
\text { units, t. }\end{array}$ & $\begin{array}{l}\text { Price per unit, } \\
\text { thousand c.u. }\end{array}$ & $\begin{array}{l}\text { Value of prod- } \\
\text { ucts, } \\
\text { thousand c.u. }\end{array}$ \\
\hline
\end{tabular}

\begin{tabular}{l|c|c|c}
\hline \multicolumn{5}{c}{ Basalt } \\
\hline 0 & 4000 & 0,06 & 240 \\
\hline 1 & 6000 & 0,06 & 360 \\
\hline 2 & 8500 & 0,06 & 510 \\
\hline 3 & 8500 & 0,06 & 510 \\
\hline 4 & 8500 & 0,06 & 510 \\
\hline $0-4$ & 34500 & 0,06 & 2070 \\
\hline 0 & Native copper \\
\hline 1 & 150 & 60 & 9000 \\
\hline 2 & 200 & 60 & 12000 \\
\hline
\end{tabular}


Continuation of table.6

\begin{tabular}{l|c|c|c}
\hline 3 & 300 & 60 & 18000 \\
\hline 4 & 350 & 60 & 21000 \\
\hline $0-4$ & 1100 & 60 & 66000 \\
\hline \multicolumn{3}{|c}{ Tuff } \\
\hline 0 & 900 & 0,04 & 36 \\
\hline 1 & 1500 & 0,04 & 60 \\
\hline 2 & 2000 & 0,04 & 80 \\
\hline 3 & 2000 & 0,04 & 80 \\
\hline 4 & 2000 & 0,04 & 80 \\
\hline $0-4$ & 8400 & 0,04 & 336 \\
\hline
\end{tabular}

Having the planned product sales volumes and current prices in the market it is possible to predict the expected income of the technology park and Rafalivka basalt quarry (Table 7) and calculate the economic feasibility of the project (Table 8 and Table 9).

Table 7

Expected income from sales of innovative products, thousands c.u.

\begin{tabular}{l|c|c|c|c|c|c}
\hline Elements & 1 & 2 & 3 & 4 & 5 & Total \\
\hline Expected income & 9276 & 12420 & 15590 & 18590 & 21590 & 74466,0 \\
\hline Investments into the project & 6500 & 3500 & & & & \\
\hline $\begin{array}{l}\text { including credit } \\
\text { investments of PJSC "Rafalivka } \\
\text { basalt quarry" }\end{array}$ & 1500 & 3500 & & & & \\
\hline Manufacturing charges & 2163,7 & 2465,9 & 2419,60 & 2391,82 & 2378,50 & 11819,6 \\
\hline $\begin{array}{l}\text { Credit repayment by technology } \\
\text { park }\end{array}$ & 1000,0 & 1875,0 & 1875,00 & 1875,00 & 1875,00 & 8500,00 \\
\hline $\begin{array}{l}\text { credit \% } \\
\text { Total credit payments }\end{array}$ & 1050 & 1575 & 1181,25 & 787,5 & 393,75 & 4987,50 \\
\hline Income after \% repayment & 5062,2 & 6504,1 & 10114,15 & 13535,7 & 16942,8 & 52158,9 \\
\hline $\begin{array}{l}\text { Profit of PJSC "Rafalivka basalt } \\
\text { quarry" (17\%) }\end{array}$ & 860,58 & 1105,7 & 1719,41 & 2301,07 & 2880,27 & 8867,01 \\
\hline
\end{tabular}

Table 8

Expected present income for technology park

\begin{tabular}{|c|c|c|c|c|c|c|c|c|}
\hline \multirow{2}{*}{ No } & \multirow{2}{*}{ Elements } & \multirow{2}{*}{$\begin{array}{l}\text { Measurement } \\
\text { unit }\end{array}$} & \multicolumn{5}{|c|}{ Years } & \multirow{2}{*}{ Total } \\
\hline & & & 1 & 2 & 3 & 4 & 5 & \\
\hline 1 & $\begin{array}{ll}\begin{array}{l}\text { Project } \\
\text { come }\end{array} & \text { in- } \\
\end{array}$ & thousands c.u. & 4201,67 & 5398,37 & 8394,75 & 11234,61 & 14062,48 & 43291,88 \\
\hline 2 & $\begin{array}{ll}\begin{array}{l}\text { Project } \\
\text { penses }\end{array} & \text { ex- } \\
\end{array}$ & thousands c.u. & 5000,00 & 3500,00 & & & & 8500,00 \\
\hline
\end{tabular}


Continuation of table. 8

\begin{tabular}{l|l|l|c|c|c|c|c|c}
\hline 3 & $\begin{array}{l}\text { Coefficient of } \\
\text { discounting } \\
(20 \%)\end{array}$ & coefficient & 1,00 & 0,69 & 0,58 & 0,48 & 0,40 & 3,15 \\
\hline 4 & $\begin{array}{l}\text { Discounted } \\
\text { income }\end{array}$ & thousands c.u. & 4201,67 & 3724,88 & 4868,95 & 5392,61 & 5624,99 & 23813,10 \\
\hline 5 & $\begin{array}{l}\text { Discounted } \\
\text { expenses }\end{array}$ & thousands c.u. & 5000,00 & 2415,00 & & & & 7415,00 \\
\hline 6 & $\begin{array}{l}\text { Net present } \\
\text { value }\end{array}$ & thousands c.u. & $-798,33$ & 1309,88 & 4868,95 & 5392,61 & 5624,99 & 16398,10 \\
\hline
\end{tabular}

So, the net present value of the project for the technology park is 16398.1 thousand c.u.

The calculation of net present value (NVP) of the project for PJSC "Rafalivka basalt quarry" is given in Table 9.

Table 9

The calculation of NVP of the project for PJSC "Rafalivka basalt quarry"

\begin{tabular}{|c|c|c|c|c|c|c|c|c|}
\hline \multirow{2}{*}{ No } & \multirow{2}{*}{ Elements } & \multirow{2}{*}{$\begin{array}{c}\text { Measurement } \\
\text { unit }\end{array}$} & \multicolumn{5}{|c|}{ Years } & \multirow{2}{*}{ Total } \\
\hline & & & 2011 & 2012 & 2013 & 2014 & 2015 & \\
\hline 1 & Project income & $\begin{array}{l}\text { thousands } \\
\text { c.u. }\end{array}$ & 860,58 & 1105,69 & 1719,41 & 2301,07 & 2880,27 & 8867,01 \\
\hline 2 & Project expenses & $\begin{array}{l}\text { thousands } \\
\text { c.u. }\end{array}$ & 1500,00 & & & & & 1500,00 \\
\hline 3 & $\begin{array}{|ll|}\begin{array}{l}\text { Coefficient } \\
\text { discounting } \\
(20 \%)\end{array} \\
\end{array}$ & coefficient & 1,00 & 0,69 & 0,58 & 0,48 & 0,40 & 3,15 \\
\hline 4 & 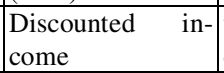 & $\begin{array}{l}\text { thousands } \\
\text { c.u. }\end{array}$ & 860,58 & 762,93 & 997,26 & 1104,51 & 1152,11 & 4877,38 \\
\hline 5 & $\begin{array}{|ll|}\begin{array}{l}\text { Discounted ex- } \\
\text { penses }\end{array} & \\
\end{array}$ & $\begin{array}{l}\text { thousands } \\
\text { c.u. }\end{array}$ & 1500,00 & & & & & 1500,00 \\
\hline 6 & Net present value & $\begin{array}{l}\text { thousands } \\
\text { c.u. }\end{array}$ & $-639,42$ & 762,93 & 997,26 & 1104,51 & 1152,11 & 3377,38 \\
\hline
\end{tabular}

Fig. 4 shows the dynamics of net present value for the PJSC "Rafalivka basalt quarry" 


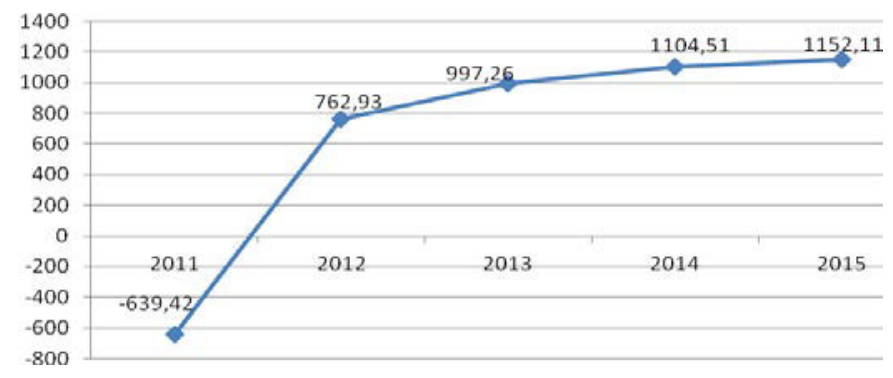

Fig. 4. The NVP dynamics of PJSC "Rafalivka basalt quarry" project

Net present value of the project is more than zero, the profitability index of the project is 3.2 , which is more than 1 , and the payback time is 1.9 years, which indicates the feasibility of the project.

After the termination of the agreement, the terms of the cooperation may be reviewed. By that time, it is possible to buy the technology and continue in-house production, or to continue joint ventures on the basis of the interest receiving from the net profit, depending on the assigned responsibilities.

Thus, the accompanying mining and sales of copper will allow the company to expand its activities and minimize the long-term risk, which will significantly improve the economic condition of the company, and Ukraine will receive additional copper concentrate in addition to basalt products.

References

1. Malanchuk Z.R., Moshynsky V.S., Korniienko V.Y., Malanchuk Ye.Z., Lozynskyi V.H. Substantiating parameters of zeolite-smectite puff-stone washout and migration with in an extraction chamber. Naukovyi Visnyk Natsionalnoho Hirnychoho Universytetu, (6), (2019), Article in press. P. 11-18.

2. Mateiuk V.V., Melnychuk V.H. Experience of basalt flows study in the traps formations of Volyn during geological survey and searching of native copper deposits. In the book: Regional geological research in Ukraine and the question of "State geologic map 2000" creation. - K: Geoinform, (2001). - P. 168-170.

3. Kvasnytsia V.M., Nesterovskyi V.A., Pavlyshyn V.I. To the finding of native copper in tuffogenic rocks of Volyn. - Mineral. Magazine. - (2000). - No. 4. - P. 20-24.

4. Nadutyi V.P., Prokopiuk O.M., Levchenko P.V. Results of researches on 
tuff weakening in dumps of basalt quarries: Geotechnical Mechanics : Interdepartmental Collection of Scientific papers. IGTM NAS of Ukraine. - Dnipropetrovsk, (2010). - Issue. 89. - P. 120-126.

5. Hryniuk T.Iu., Koziar V.O., Prokopiuk O.M. Experimental studies of physical properties of copper-bearing rocks in Volyn. Geotechnical Mechanics : Interdepartmental Collection of Scientific papers. IGTM NAS of Ukraine, - Dnipropetrovsk, (2010). - Issue. 8. - P. 270-274.

6. Nadutyi V.P., Mostyka Yu.S., Hryniuk T.Iu. Determination of magnetic susceptibility of raw materials of basalt quarry. Geotechnical Mechanics: Interdepartmental Collection of Scientific papers. IGTM NAS of Ukraine. - Dnipropetrovsk, (2008) - Issue 74. - P. 8-14.

7. Bulat A.F., Nadutyi V.P., Malanchuk Z.R.. Prospects of complex processing of basalt raw materials in Volyn. Geotechnical Mechanics : Interdepartmental Collection of Scientific papers. IGTM NAS of Ukraine. - Dnipropetrovsk, (2010). Issue 85. - P. 3-7.

8. Nadutyi V.P., Malanchuk Z.R.., Hryniuk T.Iu., Stets S.Ie. Regularities of placement of native copper in basalt lava-breccia. NUWEE Bulletin: a collection of scientific papers. - Rivne, (2005). - Issue. 4(30). - P. 25-220.

9. Nadutyi V.P., Hryniuk T.Iu. Determining of dependencies of native copper content in basalts on the mass and size of samples. Bulletin of the National Technical University "Kharkiv Polytechnic Institute": collection of scientific works. Thematic issue "Chemistry, chemical technology". - Kharkov: NTU "KPI", (2007). - No. 26. P. 87-93.

10. Melnychuk V.H., Prykhodko V.L., Kosovskyi Ya.O., Mateiuk V.V. Copper-bearing lava-breccia in Volyn's trap formations. Materials of the Scientific Conference "Geological Science and Education in Ukraine at the Boundary of the Millennium: state, problems, perspectives". - Lviv, (2000). - P. 115-116.

11. Nadutyi V.P., Malanchuk Z.R.., Prokopiuk O.N. Justification of the necessity of complex processing of zeolite-smektitic tuffs of Volyn. Materials of the International Conference "The Miners' Forum 2010". - Dnipropetrovsk: National Mining University, (2010). - P. 50-55.

12. Nadutyi V.P., Prokopiuk O.N., Budnyk V.Y. Results of magnetic susceptibility analysis of zeolite smectite tuff. Enrichment of minerals: collection of scientific works of NMU. - Dnipropetrovsk. - Issue (2011).

13. Nadutyi V.P., Prokopiuk O.N., Hryniuk T.Iu. The results of experimental studies of the regularities of grain-size distribution by classes of particle size at tuff crushing and grinding. Interdepartmental collection of scientific works of IGTM NAS of Ukraine. - Dnipropetrovsk, (2010). - Issue 91. - P. 73-76.

14. Nadutyi V.P., Yahniukov V.F., Khmelenko I.P. The patent of Ukraine on useful model UA 39362. Vibrating screen. МПКВ 07B. Order No. 4200810796 dd. 
01.09.2008. Bul. No. 4. - (2009).

15. Nadutyi V.P., Sukharev V.V. The patent of Ukraine on useful model UA 42114. МПК В 02C 2/00, В 02C 15/00 Inner-roller conical mill. Bul. No. 12 (2009).

16. Malanchuk Ye.Z., Stets S.Ie., Prokopiuk O.M. Mathematical modeling of the lay-out process of a copper-bearing rock. NUWEE Bulletin: a collection of scientific papers. - Rivne city. - Issue 4 (48), (2009). - P. 216-223.

17. V.H. Melnychuk, Kosovskyi Ya.O., Prykhodko V.L., Mateiuk V.V. Types of native copper mineralization in the trap formations of Volyn and assessment of its prospects. In the book "Geological Science and Education in Ukraine at the Boundary of the Millennium: state, problems, perspectives" Material of the scientific conference - Lviv: LNU, (2000). - P. 117-122.

18. Malanchuk Z.R.., Nadutyi V.P., Lapshyn Ye., Tokar O.I., Kalko A.D. Determination of technical properties of copper-bearing basalts in the Rivne-Volyn region and development of recommendations for pre-project comprehensive deposit development. Scientific and technical report of NUWEE No. State Register. 0109 U 001946 Rivne city. - (2010). p. 118.

19. Malanchuk Z.R., Nadutyi V.P., Tokar O.I., Koziar V.O., Ihnatiuk R.M. Study of composition, physical and mechanical properties, manufacturability of processing and enrichment of native copper from rock mass of basalt quarries. Scientific and technical report of NUWEE, Rivne city, - (2013) serial No. State Register. 0111 U 002189.

20. Malanchuk Z.R., Koretskyi M.Kh., Klements, Budzovskyi, Malanchuk Ye.Z. Prospects for copper and related metals mining in the Rivne-Volyn region of Ukraine. Collection of scientific papers "Visnyk NUWEE". - Rivne: NUWEE(2013).Issue No.1(61), P. 3-11.

21. Malanchuk Z.R., Malanchuk E.Z. The results of studies of the distribution of native copper in rock mass Volhynia (Ukraine). The 1st International Academic Congress «Fundamental and Applied Studies in the Pacific and Atlantic Oceans Countries». Japan, Tokyo, 25 October (2014). «Tokyo University Press» - P. 322-325.

22. Malanchuk Z.R., Malanchuk E.Z. The analysis of the state of the question on the content of nonferrous metals in basalt raw materials Volyn region of Ukraine. Canadian Journal of Science, Education and Culture. No. 2(6), July-December, (2014) «Toronto Press». - P. 361-365.

23. Malanchuk Z.R. Malanchuk E.Z. Zagorovsky V. Experience in the use of products processing of basalt raw material in Ukraine. American Journal of Scientific and Educational Research No. 2(5), July-December. «Columbia Press», New York. (2014). - P. 642-648.

24. Malanchuk E., Malanchuk Z., Hristuk A., Zagorovsky V. Simulation of the comminution process to complex processing of metal-bearing basalt raw material. 
Cambridge Journal of Education and Science. No.2. (14), July-December, (2015). VOLUME VI “Cambridge University Press". - P. 542-549.

25. Malanchuk Z., Malanchuk E., Ignatyuk I., Malanchuk L., Zagorovsky V. Evaluation of the possibility of complex processing of basalt raw material in Rivne-Volyn region of Ukraine. Yale Journal of Science and Education, No. 1(16). January-June (2015), USA, "Yale University Press", P. 728-735.

26. Naduty.V, Malanchuk Z., Malanchuk E., Korniyenko V.Y. Modeling of vibro screening at fine classification of metallic basalt. Theoretical and Practical Solutions of Mineral Resources Mining, (2015), London, "CRC Press Taylor and Francis Group”, A BALKEMA BOOK, P. 441-443.

27. Naduty V.P., Malanchuk Z.R., Malanchuk E.Z., Korniyenko V.Ya. Modeling of vibro screening at fine classification of metallic basalt. Metal Journal. Metallurgical and Mining Industry. No. 6. (2015). P. 86-90.

28. Malanchuk E.Z., Korniienko V.Y., Malanchuk Z.R.. Deposits of native copper in Ukraine. Collection of articles of the Scientific-Information Center "Znaniye" on the materials of the XI International Virtual Research and Practice Conference: "Science Development in the XXI Century" part 1, Kharkov: a collection of articles (standard level, academic level). - D.: Scientific-Information Center "Znaniye”, Kharkov, (2016) P. 138-142.

29. Malanchuk Z., Malanchuk E., Korniienko V., Gromachenko S. The results of magnetic separation use in ore processing of metalliferous raw basalt of Volyn region. Journal «Mining of Mineral Deposits» / National Mining University, Dnipropetrovsk, Ukraine. ISSN 2415-3443, Volume 10, Issue 3. - (2016). P. 77-83.

30. Malanchuk Z.R., Nadutyi V.P., Tymoshenko I.O. A method of preparation of copper-bearing basalts for complex enrichment. Patent No.42265 of 25.06.2009. published in bulletin No.72, (2009).

31. Naduty.V, Malanchuk Z., Malanchuk E., Korniienko V. Research results proving the dependence of the copper concentrate amount recovered from basalt raw material on the electric separator field intensity. Eastern - European Journal of Enterprise Technologies / PC «TECHNOLOGY CENTER», Kharkiv, Ukraine, Volume 5/5(83), - (2016). P. 19-24.

32. Nadutyi V.P., Malanchuk Z.R., Malanchuk E.Z., Korniienko V.Y. Vibratory sieving simulation for improvement of metal extraction from basalt. Metallurgical and mining industry, Collection of scientific papers. Metallurgical Academy. Dnepr. Issue No.3, (2016) P. 102-104.

33. Malanchuk E.Z. Technology and Management of Hydro-mining of mineral deposits / Monography // Under editorship of Doctor of Technical Sciences, Professor, Malanchuk Z.R. - Rivne: NUWEE, (2009). - 480 p.

34. Malanchuk E.Z., Malanchuk Z.R., Korniyenko V.Ya. Efficiency of using magnetic separation for the processing of metal-containing basalt raw materials. Topical issues of resource-saving technologies in mineral mining and processing. Multi-authored monograph. - Petro Sani, Romania: UNIVERSITAS Publishing, (2018). - 270 p., C. 65-89. 